\title{
CXLIX. ON THE PURINE METABOLISM OF THE DALMATIAN COACH HOUND
}

\author{
BY ELRID GORDON YOUNG, CATHERINE FRANCES CONWAY \\ AND WILLIAM ALLISTER CRANDALL \\ From the Department of Biochemistry, Dalhousie University, \\ Halifax, Canada
}

(Received 28 May 1938)

THE remarkable differences in purine metabolism as to synthesis and uricolysis amongst vertebrates have recently been emphasized by Brunel [1937] in contrasting the mammal with the amphibian, reptile and bird. Even in the mammal the uricolytic index in man and the higher apes is $0-2$ whereas in most mammals it is $90-98$. In a few it is intermediate as in the horse, 88 , sheep, 80 and opossum, 79 [Hunter \& Givens, 1914]. This is also true of the New World monkeys [Rheinberger, 1936]. Benedict [1916] first reported the unusual purine metabolism of the Dalmatian coach hound with an index of about 30 and demonstrated the synthesis of purines in this animal on diets essentially purinefree.

The work of Terroine et al. [1931-32] with the pig suggests an inverse relationship between the $\mathrm{N}$ retention and the level of purine excretion on purinefree diets, high and low in protein. In complete inanition in the rat, as well as on a low protein intake, the loss of tissue purines did not account for the amount excreted. These authors conclude that a synthesis of purines takes place at the expense of either tissue protein or, under normal conditions, dietary protein. Degan [1933] and Kapeller-Adler et al. [1934] have come to essentially the same conclusions.

The material for this synthesis in mammals is not established and forms the main subject of this investigation. The literature has been reviewed in the preceding paper [Crandall \& Young, 1938] in which evidence supporting the thesis that histidine is the essential amino-acid was obtained from feeding experiments with ordinary puppies on synthetic diets containing casein, haemoglobin or arachin.

The Dalmatian provides an experimental animal excreting considerable amounts of uric acid and therefore suited to metabolic experiments with synthetic diets selected to contrast the effects of different amino-acids on the excretion of purines.

\section{EXPERIMENTAL}

Two Dalmatian bitches, 3 months old, of registered pedigrees, were confined in metabolic cages intermittently over a period of several months. The urine, collected under toluene after passing through a fine mesh screen, was removed every $24 \mathrm{hr}$. The daily output of about $350 \mathrm{ml}$. was diluted to 1 litre and the reaction adjusted to neutrality or slight alkalinity. On the diets given the urine tended to be alkaline and to deposit crystalline ammonium magnesium phosphate. The dogs were weighed every 4 or 5 days. For the greater part of the experiment they gained slowly in weight. At no time were the dogs ill, but they lost their appetites on certain diets. Water was given ad libitum and food twice daily. 
Methods. Urinary constituents were determined by the following methods: total N, Kjeldahl; urea and $\mathrm{NH}_{3}$, Van Slyke-Cullen; creatine and creatinine, Folin micro-methods; uric acid, Christman \& Ravwitch [1932]; allantoin, Larson [1932] and occasionally Christman [1926].

Diets. In general we have followed the basal requirements of Cowgill [1923]. Previous experience with puppies led us to adopt the levels of $100 \mathrm{Cal}$. and $1 \mathrm{~g}$. protein $\mathrm{N}$ per $\mathrm{kg}$. body wt. To the calculated amount of protein, previously analysed, were added sucrose and lard such that the fat did not exceed $25 \%$ of the total weight of the daily ration. Yeast concentrate, halibut liver oil, salt mixture and bone ash were added as previously described [Crandall \& Young, 1938]. Single proteins were fed on the basis of $N$ equivalence, forming the only variable in the diet. The period for each diet was approximately 1 week but depended on palatability and the constancy in the level of excretory products. Casein was adopted as standard protein for comparison, and other proteins selected to provide a high intake of particular amino-acids were arachin (arginine), haemoglobin (histidine), serum albumin (cystine), gelatin (glycine). Serum albumin and haemoglobin are also high in leucine and isoleucine, casein in glutamic and hydroxyglutamic acids, and gelatin in proline and hydroxyproline.

Haemoglobin and a mixture of arachin with conarachin were prepared as in the preceding paper [Crandall \& Young, 1938]. The casein, serum albumin and gelatin were commercial samples in powdered form. The meat protein was obtained from minced lean round steak by boiling in water at $p \mathrm{H} 5$ for $15 \mathrm{~min}$., filtering, re-mincing and re-boiling twice, and drying in air. All protein preparations used were analysed for their content of moisture, protein, fat and ash. These figures were used in the calculations of the specific diets recorded in Tables I and III.

There is a disturbing discrepancy in the values for histidine in casein recorded in the literature. The most recent figure of $11 \%$ [Kapeller-Adler, 1933] is almost double the older values of $\mathbf{6 \cdot 2 - 6 \cdot 6 \%}$ of Van Slyke and Crowther \& Raistrick, and if confirmed this value would disturb the contrast between casein and haemoglobin.

Preformed purines in diets. These were determined in our protein preparations after initial hydrolysis by the method of Graff \& Maculla [1935] and the results were as follows: casein, 14; haemoglobin, 43 ; peanut meal, 17; serum albumin, 22; gelatin, 0 ; meat powder, 35; purina powder, 24; expressed as mg. purine $\mathbf{N}$ per $100 \mathrm{~g}$. stock preparation. The amounts of preformed purines consumed daily are listed in Tables I and III. These values are not insignificant but are small compared with the fluctuations observed and in relation to the total purine excretion. The dietary purine $\mathrm{N}$ would be about $5-10 \%$ or less of the urinary purine $\mathrm{N}$ in Exp. I and $10 \%$ or less in Exp. II.

\section{Exp. I. Tanya of Tattoo}

The sequence of the diets and their composition are given in Table I, including the calculated consumption of particular amino-acids for comparison with the amounts of uric acid and allantoin excreted. The calculations have been made for the most part from the data given by Mitchell \& Hamilton [1929]. Where any discrepancies in sequence of dates occur the animal had been removed from the cage and fed the diet of the subsequent period.

The first three diets were given at a level of $100 \mathrm{Cal}$. and $1 \mathrm{~g}$. protein $\mathrm{N}$ per kg. body wt. Because the weight of the animal remained stationary during this period the level was increased to $150 \mathrm{Cal}$. and $1.5 \mathrm{~g}$. protein $\mathrm{N}$ for the diets following, introduced by a long period of 3 weeks on casein. A period of 6 days without food followed to determine minimal levels of purine excretion after the 


\begin{tabular}{|c|c|c|c|c|c|c|c|c|c|c|c|c|}
\hline Diet & $\begin{array}{c}\text { Wt. } \\
\text { of } \\
\text { animal } \\
\text { kg. }\end{array}$ & $\begin{array}{c}\text { Protein } \\
\text { N per } \\
\text { kg. } \\
\text { g. }\end{array}$ & $\begin{array}{c}\text { Cal. } \\
\text { per } \\
\mathrm{kg} .\end{array}$ & $\begin{array}{c}\text { Pro- } \\
\text { tein } \\
\text { g. }\end{array}$ & $\begin{array}{c}\text { Lard } \\
\text { g. }\end{array}$ & $\begin{array}{c}\text { Suc- } \\
\text { rose } \\
\text { g. }\end{array}$ & $\begin{array}{c}\text { Purine } \\
\text { N } \\
\text { mg. }\end{array}$ & $\begin{array}{c}\text { Arginine } \\
\mathbf{N} \\
\text { g. }\end{array}$ & $\begin{array}{l}\text { Histidine } \\
\mathbf{N} \\
\mathrm{g} .\end{array}$ & $\begin{array}{l}\text { Lysine } \\
\text { N } \\
\text { g. }\end{array}$ & $\begin{array}{c}\text { Cystine } \\
\text { N } \\
\text { g. }\end{array}$ & $\begin{array}{c}\text { Glycine } \\
\mathbf{N} \\
\mathrm{g} .\end{array}$ \\
\hline asei & $4 \cdot 7$ & $1 \cdot 0$ & 100 & 39 & 20 & 40 & $5 \cdot 5$ & 0.348 & 0.292 & 0.485 & 0.094 & $0 \cdot 023$ \\
\hline & 4.9 & 1.0 & 100 & 44 & 10 & 46 & 6 . & $1 \cdot 1$ & & & & $0 \cdot 103$ \\
\hline lobin & $5 \cdot 0$ & 1.0 & 100 & 32 & 20 & 48 & $13 \cdot 7$ & 0.384 & 0.635 & 0.545 & 0.000 & 0.023 \\
\hline Case & $5 \cdot 1$ & 1.5 & 150 & 63 & 3 & 64 & $8 \cdot 4$ & 0.563 & 0.472 & $0 \cdot 784$ & 0.015 & 0.037 \\
\hline Serum albumin & $7 \cdot 5$ & 1.5 & 150 & 94 & 4 & 75 & 20.8 & $1 \cdot 175$ & 0.757 & $1 \cdot 840$ & 0.395 & 0.000 \\
\hline . & $6 \cdot 9$ & 1.5 & 150 & 73 & 40 & 90 & 0.0 & 1.513 & 0.463 & $0 \cdot 650$ & 0.010 & 2.740 \\
\hline ein $(n$ & $6 \cdot 8$ & 0.35 & 74 & 20 & 20 & 65 & $2 \cdot 8$ & $0 \cdot 178$ & 0.149 & 0.248 & $0.00 \tilde{\Xi}$ & 0.012 \\
\hline ein & $7 \cdot 3$ & 1.0 & 100 & 60 & 20 & 88 & $8 \cdot 4$ & 0.539 & 0.453 & 0.753 & 0.015 & 0.035 \\
\hline
\end{tabular}

unsuccessful use of placental protein. Gelatin was next given because of its incompleteness and to stimulate endogenous metabolism by the specific dynamic action of glycine. This was followed by casein given first at a minimum level corresponding with the endogenous requirement of the inanition period and then on the initial basis. The dog lost weight only during the starvation period.

Table II. Average composition of urine

\begin{tabular}{|c|c|c|c|c|c|c|c|c|}
\hline Date & Diet & $\begin{array}{l}\text { Diet } \\
\mathbf{N} \\
\text { g. }\end{array}$ & $\begin{array}{c}\text { Total } \\
\text { N } \\
\text { g. }\end{array}$ & $\begin{array}{c}\text { Creatinine } \\
\mathbf{N} \\
\mathbf{m g} .\end{array}$ & $\begin{array}{c}\text { Creatine } \\
\mathrm{N} \\
\mathrm{mg} .\end{array}$ & $\begin{array}{c}\text { Uric } \\
\text { acid } \\
\mathbf{N} \\
\mathbf{m g} .\end{array}$ & $\begin{array}{c}\text { Allan- } \\
\text { toin N } \\
\text { mg. }\end{array}$ & $\begin{array}{l}\text { Uri- } \\
\text { colytic } \\
\text { index }\end{array}$ \\
\hline 8-12 April & Casein & $4 \cdot 7$ & $2 \cdot 16$ & $31 \cdot 6$ & $43 \cdot 2$ & 119 & 228 & 66 \\
\hline 13 April-10 May & Arachin & 4.9 & $2 \cdot 15$ & $33 \cdot 4$ & $47 \cdot 8$ & 59 & 228 & 80 \\
\hline 15-22 May & Haemoglobin & $5 \cdot 0$ & $4 \cdot 31$ & $34 \cdot 8$ & $32 \cdot 2$ & 38 & 220 & 85 \\
\hline 24 May-13 June & Casein & $7 \cdot 6$ & 4.08 & $43 \cdot 9$ & $15 \cdot 6$ & 72 & 318 & 82 \\
\hline 18-29 June & Serum albumin & $11 \cdot 3$ & $4 \cdot 71$ & $56 \cdot 0$ & $9 \cdot 1$ & 88 & 308 & 78 \\
\hline 3-8 July & No food & - & $2 \cdot 44$ & $67 \cdot 9$ & $14 \cdot 5$ & 66 & 126 & 66 \\
\hline 9-10 July & Gelatin & $10 \cdot 3$ & $6 \cdot 76$ & 61.9 & 30.9 & 62 & 567 & 90 \\
\hline 17-23 July & Casein & $2 \cdot 4$ & 1.84 & $61 \cdot 5$ & $21 \cdot 4$ & 65 & 249 & 79 \\
\hline 25-30 July & Casein & $7 \cdot 3$ & $3 \cdot 76$ & $70 \cdot 1$ & $9 \cdot 8$ & 71 & 347 & 83 \\
\hline
\end{tabular}

The results of the urinary analyses are tabulated as averages for the respective periods in Table II. During the first three periods the only notable change was a decline in the level of uric acid excretion. The allantoin remained remarkably constant despite the fact that in the peanut meal three times more arginine was ingested and one-fifth the amount of histidine. Although the values for uric acid in the introductory period were constant we do not consider the level as representative of the casein but rather of the previous dietary history. This is evident especially when compared with the second longer casein period with a higher intake of protein and a higher total $\mathrm{N}$ yet a lower uric acid output. In this period it required over 1 week for the animal to reach the maximum level of excretion of total $\mathrm{N}$. The serum albumin provided the highest intake of cystine and also of histidine and lysine yet the products of excretion were essentially the same as for the previous casein period. At this high level of protein intake there is a marked difference between the total $\mathrm{N}$ of the food and of the urine.

Inanition for 6 days reduced the excretion of uric acid to the level observed on previous diets and the allantoin to the lowest recorded. Gelatin for 2 days at this juncture had a tremendous effect on the excretion of allantoin but did not affect the uric acid, due possibly to active synthesis of tissue proteins after starvation, or the conversion of protein into carbohydrate, or the appearance of some urinary compound other than allantoin affecting the Larson copper reduction method. The final periods at different levels of casein intake demonstrate the relative independence of uric acid but the response of allantoin. 
Generalizing from this experiment uric acid excretion has been found to be remarkably independent of diet. Allantoin on the other hand fluctuates without convincing relationship to any amino-acid studied and follows more closely the total $\mathrm{N}$ of the urine.

\section{Exp. II. Topper of Tattoo}

The sequence and composition of diets with this animal are recorded in Table III. We began this experiment by contrasting (with the adopted normal) the effects of diets high and low in casein. With these two exceptions all diets were computed on the basis of $100 \mathrm{Cal}$. and $1 \mathrm{~g}$. protein $\mathrm{N}$ per $\mathrm{kg}$. body wt.

\section{Table III. Composition of diets}

\begin{tabular}{|c|c|c|c|c|c|c|c|c|c|c|c|}
\hline Diet & $\begin{array}{c}\text { Wt. } \\
\text { of } \\
\text { animal } \\
\text { kg. }\end{array}$ & $\begin{array}{c}\text { Protein } \\
\text { N per } \\
\text { kg. } \\
\text { g. }\end{array}$ & $\begin{array}{c}\text { Pro- } \\
\text { tein } \\
\text { g. }\end{array}$ & $\begin{array}{c}\text { Lard } \\
\text { g. }\end{array}$ & $\begin{array}{c}\text { Sucrose } \\
\text { g. }\end{array}$ & $\begin{array}{c}\text { Purine } \\
\mathbf{N} \\
\mathbf{m g} .\end{array}$ & $\begin{array}{l}\text { Arginine } \\
\text { N } \\
\text { g. }\end{array}$ & $\begin{array}{c}\text { Histi- } \\
\text { dine } \mathbf{N} \\
\text { g. }\end{array}$ & $\begin{array}{c}\text { Lysine } \\
\mathbf{N} \\
\text { g. }\end{array}$ & $\begin{array}{c}\text { Cystine } \\
\mathbf{N} \\
\mathrm{g} .\end{array}$ & $\begin{array}{c}\text { Glycine } \\
\mathbf{N} \\
\mathrm{g} .\end{array}$ \\
\hline Casein-r & $9 \cdot 3$ & 1 & 68 & 25 & 117 & $9 \cdot 5$ & $0 \cdot 69$ & 0.58 & 0.96 & 0.020 & 0.045 \\
\hline Case & $9 \cdot 5$ & $0 \cdot 3$ & 26 & 39 & 126 & $3 \cdot 6$ & $0 \cdot 24$ & $0 \cdot$ & $0 \cdot 33$ & & 0.015 \\
\hline Casein-maximum & $9 \cdot 5$ & 2 & 158 & 30 & 6 & $22 \cdot 2$ & 1.41 & $1 \cdot 18$ & 1.96 & 0 . & 0.091 \\
\hline Ser & $10 \cdot 0$ & $\mathbf{l}$ & 90 & 60 & 36 & $19 \cdot 8$ & $1 \cdot 0$ & 0 . & $1 \cdot 63$ & & 0.000 \\
\hline Ar & $9 \cdot 6$ & 1 & 117 & 40 & 62 & 19.9 & 2 & 0 . & 0 . & 0 . & 0.202 \\
\hline globin & $10 \cdot 4$ & $\overline{1}$ & 70 & 50 & 88 & $30 \cdot 2$ & 0.8 & 1 . & 1 . & 0 . & 0.046 \\
\hline Gelatin & $10 \cdot 3$ & 1 & 68 & 50 & 87 & $0 \cdot 0$ & 1.52 & 0.46 & $0 \cdot 6 \dot{5}$ & $0 \cdot \mathrm{c}$ & $2 \cdot 740$ \\
\hline Casein & $10 \cdot 1$ & 1 & 89 & 50 & 89 & $12 \cdot 5$ & 0.75 & $0 \cdot 63$ & $1 \cdot 04$ & 0.020 & 0.485 \\
\hline Meat proteins & $11 \cdot 0$ & 1 & 83 & 60 & 65 & $29 \cdot 0$ & $1 \cdot 46$ & 0.55 & $1 \cdot 23$ & $0 \cdot 121$ & 0.258 \\
\hline
\end{tabular}

\section{Table IV. Average composition of urine}

\begin{tabular}{|c|c|c|c|c|c|c|c|c|}
\hline Date & Diet & $\begin{array}{l}\text { Diet } \\
\text { N } \\
\mathrm{g} .\end{array}$ & $\begin{array}{c}\text { Total } \\
\mathbf{N} \\
\mathbf{g} .\end{array}$ & $\begin{array}{c}\text { Creatinir } \\
\mathbf{N} \\
\mathbf{m g} .\end{array}$ & $\begin{array}{l}\text { Greatine } \\
\text { N } \\
\text { mg. }\end{array}$ & $\begin{array}{l}\text { Uric } \\
\text { acid N } \\
\text { mg. }\end{array}$ & 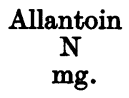 & $\begin{array}{c}\text { Uri- } \\
\text { colytic } \\
\text { index }\end{array}$ \\
\hline $\begin{array}{l}\text { 14-27 Jan. } \\
\text { 28 Jan.-4 Feb. } \\
\text { 5-7 Feb. } \\
\text { 16-23 Feb. } \\
\text { 27 Feb.-8 Mar. } \\
\text { 9-13 Mar. } \\
\text { 17-23 Mar. } \\
\text { 24 Mar.-1 April } \\
\text { 22-30 April }\end{array}$ & $\begin{array}{l}\text { Casein-normal } \\
\text { Casein-minimum } \\
\text { Casein-maximum } \\
\text { Serum albumin } \\
\text { Arachin } \\
\text { Haemoglobin } \\
\text { Gelatin } \\
\text { Casein } \\
\text { Meat protein }\end{array}$ & $\begin{array}{r}9 \cdot 3 \\
3 \cdot 2 \\
19 \cdot 0 \\
10 \cdot 0 \\
9 \cdot 8 \\
10 \cdot 4 \\
10 \cdot 3 \\
10 \cdot 1 \\
11 \cdot 0\end{array}$ & $\begin{array}{r}6 \cdot 81 \\
2 \cdot 43 \\
16 \cdot 34 \\
9 \cdot 47 \\
6 \cdot 41 \\
8 \cdot 96 \\
10 \cdot 84 \\
6 \cdot 77 \\
5 \cdot 74\end{array}$ & $\begin{array}{r}79 \\
79 \\
93 \\
88 \\
80 \\
100 \\
100 \\
89 \\
102\end{array}$ & $\begin{array}{r}17 \\
19 \\
14 \\
4 \\
4 \\
2 \\
0 \\
63 \\
16 \\
47\end{array}$ & \begin{tabular}{r|}
88 \\
82 \\
126 \\
$\cdot 100$ \\
85 \\
112 \\
57 \\
110 \\
61
\end{tabular} & $\begin{array}{l}88 \\
101 \\
129 \\
40(?) \\
150 \\
110 \\
55 \\
? \\
115\end{array}$ & $\begin{array}{l}50 \\
55 \\
51 \\
29 \\
64 \\
50 \\
49 \\
? \\
65\end{array}$ \\
\hline
\end{tabular}

The salient points observable from a comparison of Tables III and IV may be summarized as follows.

(1) A reduction in the protein $\mathrm{N}$ intake from $9 \cdot 3$ to $3 \cdot 2 \mathrm{~g}$. made no difference in the excretion of uric acid and allantoin. An increase to $19.0 \mathrm{~g}$. with a very high urinary $\mathrm{N}$ augmented the level of purine excretion very slightly, but in our opinion significantly.

(2) The uricolytic index was characteristic of the diet as well as of the dog. Thus casein, haemoglobin and gelatin provided an index of 50 while serum albumin lowered it to 29 and peanut meal raised it to 65 . The figures for allantoin obtained with serum albumin and in the last casein period are in some doubt and are probably too low, due to a tendency for cloudiness to develop during the determination. In the last casein period the determinations obtained were too few to warrant an average.

(3) The exogenous supply of cystine cannot be related to the purine excretion. On the minimum casein diet the intake of cystine $\mathrm{N}$ was $6 \mathrm{mg}$. and the output of purine $\mathrm{N}$ was $184 \mathrm{mg}$. On the serum albumin diet the intake was $443 \mathrm{mg}$. and the output $140 \mathrm{mg}$. 


\section{E. G. YOUNG, C. F. CONWAY AND W. A. CRANDALL}

(4) The effect of gelatin is noteworthy in that despite a negative $\mathrm{N}$ balance, the excretion of total purines is the lowest in the experiment. The effect on the excretion of creatine is interesting and was also observed in the first animal (Table II). It suggests a sudden synthesis from glycine.

(5) The relationship of either arginine or histidine to purine synthesis is not obvious. On the second lowest intake of histidine, $270 \mathrm{mg}$., in peanut meal, we obtained the highest excretion of allantoin. Arginine appears more closely related to purine excretion but this relationship is not demonstrated in convincing manner in this experiment. Thus on the minimum casein diet containing $240 \mathrm{mg}$. arginine $\mathrm{N}, 184 \mathrm{mg}$. purine $\mathrm{N}$ were excreted. On the maximum arginine content in peanut meal however we did obtain the highest excretion of allantoin, despite a low figure for the total urinary $\mathrm{N}$. This points to a possible further difference between the Dalmatian and other dogs in their purine metabolism.

\section{Effect of supplementary amino-acids}

Following the usual procedure of adding pure amino-acids to a basal diet in an effort to demonstrate a linear relationship to an excretory product we have used arginine, histidine and glycine. At this time the dog tended to lose her appetite and would not consume the daily rations quantitatively. We were compelled to make use of coagulated protein from ox muscle as basal diet. Material, prepared identically, has been analysed by Rosedale [1922] and Jones et al. [1924] whose analyses have been used in Table III: this powder however contained some nucleoprotein. After an introductory period the amino-acids, as hydrochlorides, were added. The Christman method for allantoin was used in these analyses. The variation of purine excretion on the basal diet is somewhat disconcerting-especially with a constant excretion of creatinine. The output of uric acid rose slightly after both arginine and histidine, and that of allantoin definitely after $3 \mathrm{~g}$. histidine. The histidine effect was repeated later with the same animal and compared with an equivalent amount of glycine but the latter was without effect.

\section{Effect of preformed purines}

Our results on the administration of preformed purines, either free or in combined form as nucleic acid, have tended to show a constancy in uric acid as compared with allantoin. We wished to know whether the present conceptions of pathways to uric acid and allantoin held in the Dalmatian. Wells [1918] has shown the existence in the liver of adenase, guanase and uricase but the absence of xanthine oxidase. The effect of feeding thymus was an increased elimination of both uric acid and allantoin with a rise in the uricolytic index as observed by Benedict [1916]. Allen \& Cerecedo [1933] have found that guanine is metabolized to allantoin and in part to urea in the ordinary dog.

The purines used in our experiments were obtained from Hoffmann-La Roche Inc., Basel, Switzerland. We have added them in capsules to a basal diet of purina dog chow. This became necessary because the dog could not be depended upon to maintain her appetite for a sufficiently long period otherwise. The ordinary checkers were ground, moistened and used as the basal ration unsupplemented. In that the daily portion was consumed quantitatively the presence of preformed purine material was not considered a serious objection.

The Larson method for allantoin was again used in this series of experiments.

Table $\mathrm{V}$ represents the results condensed where possible. Guanine and xanthine caused appreciable increases in allantoin. Uric acid itself, per os in small amounts, had a similar effect. Nucleic acid increased the output of uric acid slightly, allantoin and urea definitely. At times notable increases in $\mathbf{N H}_{3}$ 
Table V. Effects of supplementary purines

\begin{tabular}{|c|c|c|c|c|c|c|c|c|c|}
\hline Date & $\begin{array}{l}\text { Total } \\
\text { N } \\
\text { g. }\end{array}$ & $\begin{array}{l}\text { Urea } \\
\text { N } \\
\text { g. }\end{array}$ & $\begin{array}{c}\underset{\mathrm{N}}{\text { Ammonia }} \\
\mathrm{g} .\end{array}$ & $\begin{array}{c}\text { Creatine } \\
\mathbf{N} \\
\mathbf{m g} .\end{array}$ & $\begin{array}{c}\text { Creatinine } \\
\mathrm{N} \\
\mathrm{mg}\end{array}$ & $\begin{array}{l}\text { Uric } \\
\text { acid N } \\
\text { mg. }\end{array}$ & $\begin{array}{c}\text { Allantoin } \\
\mathbf{N} \\
\mathbf{m g}\end{array}$ & $\begin{array}{l}\text { Uri- } \\
\text { colytic } \\
\text { index }\end{array}$ & Remarks \\
\hline 29 May-2 June & $7 \cdot 04$ & $5 \cdot 54$ & $0 \cdot 732$ & 40 & 105 & 125 & 310 & 71 & Basal diet \\
\hline $\begin{array}{l}3 \text { June } \\
4 \quad, \\
5 \quad,\end{array}$ & $\begin{array}{l}7 \cdot 69 \\
6 \cdot 95 \\
8 \cdot 78 \\
7 \cdot 81\end{array}$ & $\begin{array}{l}6 \cdot 33 \\
5 \cdot 64 \\
6 \cdot 78 \\
6 \cdot 25\end{array}$ & $\begin{array}{l}0 \cdot 687 \\
0 \cdot 626 \\
0 \cdot 914 \\
0 \cdot 742\end{array}$ & $\begin{array}{l}43 \\
48 \\
57 \\
49\end{array}$ & $\begin{array}{l}99 \\
99 \\
99 \\
99\end{array}$ & $\begin{array}{l}140 \\
116 \\
148 \\
135\end{array}$ & $\begin{array}{l}352 \\
452 \\
532 \\
445\end{array}$ & $\begin{array}{l}72 \\
80 \\
78 \\
77\end{array}$ & +1 g. guanine \\
\hline $\begin{array}{c}6 \text { June } \\
7 \quad, \\
8 \quad, \\
9 \quad, \\
10 \quad,\end{array}$ & $\begin{array}{l}6 \cdot 89 \\
8 \cdot 33 \\
9 \cdot 95 \\
7 \cdot 89 \\
8 \cdot 16 \\
8 \cdot 24\end{array}$ & $\begin{array}{l}5 \cdot 38 \\
7 \cdot 11 \\
8 \cdot 23 \\
6 \cdot 36 \\
6 \cdot 92 \\
6 \cdot 80\end{array}$ & $\begin{array}{l}1 \cdot 237 \\
0 \cdot 847 \\
0 \cdot 810 \\
0 \cdot 634 \\
0 \cdot 902 \\
0.798\end{array}$ & $\begin{array}{l}14 \\
60 \\
14 \\
14 \\
48 \\
30\end{array}$ & $\begin{array}{r}88 \\
92 \\
103 \\
103 \\
99 \\
97\end{array}$ & $\begin{array}{l}106 \\
141 \\
121 \\
103 \\
111 \\
116\end{array}$ & $\begin{array}{l}400 \\
395 \\
585 \\
490 \\
479 \\
470\end{array}$ & $\begin{array}{l}79 \\
74 \\
83 \\
83 \\
81 \\
80\end{array}$ & $\begin{array}{l}+0.5 \mathrm{~g} . \text { xanthine } \\
+0.5 \mathrm{~g} \text {. xanthine }\end{array}$ \\
\hline $\begin{array}{l}11 \text { June } \\
12 \text {," } \\
13 \text { ", } \\
14 \text {," } \\
15 \text {, }\end{array}$ & $\begin{array}{l}7 \cdot 41 \\
8 \cdot 13 \\
8 \cdot 39 \\
7 \cdot 75 \\
8 \cdot 74 \\
8 \cdot 08\end{array}$ & $\begin{array}{l}5 \cdot 84 \\
6 \cdot 50 \\
6 \cdot 45 \\
6 \cdot 53 \\
7 \cdot 24 \\
6 \cdot 51\end{array}$ & $\begin{array}{l}0 \cdot 677 \\
0 \cdot 558 \\
1 \cdot 167 \\
0 \cdot 646 \\
0 \cdot 714 \\
0 \cdot 752\end{array}$ & $\begin{array}{l}37 \\
43 \\
17 \\
39 \\
42 \\
36\end{array}$ & $\begin{array}{r}95 \\
99 \\
95 \\
99 \\
115 \\
101\end{array}$ & $\begin{array}{r}87 \\
119 \\
89 \\
121 \\
112 \\
106\end{array}$ & $\begin{array}{l}300 \\
346 \\
441 \\
350 \\
425 \\
372\end{array}$ & $\begin{array}{l}77 \\
75 \\
83 \\
74 \\
79 \\
78\end{array}$ & $\begin{array}{l}+0.5 \mathrm{~g} \text {. uric acid } \\
+0.5 \mathrm{~g} \text {. uric acid }\end{array}$ \\
\hline $\begin{array}{l}16 \text { June } \\
17 \text { ", } \\
18 \text { ", }\end{array}$ & $\begin{array}{l}7 \cdot 58 \\
8 \cdot 95 \\
9 \cdot 77 \\
8 \cdot 77\end{array}$ & $\begin{array}{l}6 \cdot 12 \\
7 \cdot 13 \\
8 \cdot 04 \\
7 \cdot 10\end{array}$ & $\begin{array}{l}0 \cdot 573 \\
0 \cdot 733 \\
0 \cdot 774 \\
0 \cdot 693\end{array}$ & $\begin{array}{l}40 \\
40 \\
32 \\
37\end{array}$ & $\begin{array}{l}100 \\
101 \\
110 \\
104\end{array}$ & $\begin{array}{r}82 \\
136 \\
129 \\
116\end{array}$ & $\begin{array}{l}350 \\
690 \\
438 \\
493\end{array}$ & $\begin{array}{l}81 \\
83 \\
77 \\
81\end{array}$ & $\begin{array}{l}+1 \text { g. nucleic acid } \\
+2 \text { g. nucleic acid } \\
+2 \text { g. nucleic acid }\end{array}$ \\
\hline 19-28 June & $7 \cdot 74$ & $6 \cdot 42$ & $0 \cdot 757$ & 42 & 99 & 91 & 377 & 80 & \\
\hline
\end{tabular}

are recorded. They may represent bacterial fermentation in the urine during collection or a degradation of the purine nucleus. The most remarkable observation in this experiment was the constancy in the excretion of uric acid despite distinct changes in the excretion of allantoin. It suggests that in the Dalmatian there is an endogenous metabolism of uric acid distinct from that of allantoin.

A difference has been noted in results of administering purines by capsule or mixed with the food. In the latter method adenine and guanine appear to be degraded and excreted in a non-purine form. We have fed hypoxanthine and xanthine in quantities of $1 \mathrm{~g}$. in like manner but without any perceptible effect on the $\mathrm{N}$ excretory products.

\section{Discussion}

Briefly stated there are three conceptions of the origin of urinary purines in mammals on essentially purine-free diets. The first empirically relates the production of purines to the extent of the metabolism of carbohydrates. The second draws a parallel between the specific dynamic action of food and the catabolic production of purines. This indicates a closer but non-specific relationship to endogenous metabolism. The third pictures a synthesis from a nitrogenous precursor to provide nuclear material for growth and repair with excretion of plethora as uric acid or allantoin. This indicates a specific relationship to exogenous metabolism. The experiments in this paper have been based on the third hypothesis. The behaviour of allantoin in our experiments appears to fit the third conception and that of uric acid the second. But the evidence presented above does not indicate any apparent specificity and on the same diet there was considerable fluctuation from day to day. The daily volume of urine was not measured and may have accounted for this variation as has been suggested by Krafka [1932].

The uricolytic index of the Dalmatian as recorded by different observers varies considerably. Our first dog, Tanya, showed an index of 66-90, average, 80; 


\section{REFERENCES}

Allen \& Cerecedo (1933). J. biol. Chem. 102, 313.

Benedict (1916). J. Lab. clin. Med. 2, 1.

Brunel (1937). Bull. Soc. Chim. biol., Paris, 19, 1683.

Christman (1926). J. biol. Chem. 70, 173.

— \& Ravwitch (1932). J. biol. Chem. 95, 115.

Cowgill (1923). J. biol. Chem. 56, 725.

Crandall \& Young (1938). Biochem. J. 32, 1133.

Degan (1933). Ann. physiol. Physicochim. biol. 9, 451, 469 and 481.

Folin (1905). Amer. J. Physiol. 13, 66.

Graff \& Maculla (1935). J. biol. Chem. 110, 71.

Hunter \& Givens (1914). J. biol. Chem. 17, 37 and 55.

Jones, Gersdorff \& Moeller (1924). J. biol. Chem. 62, 183.

Kapeller-Adler (1933). Biochem. Z. 264, 131:

Lauda \& von Megay (1934). Biochem. Z. 269, 254.

Krafka (1932). J. Lab. clin. Med. 17, 428.

Larson (1932). J. biol. Chem. 94, 727.

Mitchell \& Hamilton (1929). The Biochemistry of the Amino Acids, pp. 186-92. (New York: Chemical Catalog Co.)

Onslow (1923). Biochem. J. 17, 334.

Rheinberger (1936). J. biol. Chem. 115, 343.

Rosedale (1922). Biochem. J. 16, 27.

Terroine \& Mourot (1931). Bull. Soc. Chim. biol., Paris, 13, 94. Giaja \& Boyle (1932). Bull. Soc. Chim. biol., Paris, 14, 900.

Watanabe (1917). J. Urol, 1, 485.

Wells (1918). J. biol. Chem. 35, 221. 